\title{
GENDER PERSPECTIVE ON TEACHER-PUPIL CLASSROOM INTERACTION: FEEDBACK AND EVALUATION
}

\author{
Margareta BAŠARAGIN, Svenka SAVIĆ \\ Womens'Studies and Research, Novi Sad, Serbia; Faculty of Philosophy, University of Novi \\ Sad, Serbia
}

Bašaragin, M., Savić, S. (2019). Gender perspective on teacher-pupil classroom interaction: Feedback and evaluation. Slovenščina 2.o, 7(2): 172-196.

DOI: https://doi.org/10.4312/slo2.0.2019.2.172-196

\begin{abstract}
Various studies confirm the existence of gender bias in classroom interaction and the unequal treatment of boys and girls. The aim of this paper is to determine the differences in the type of teacher feedback after female and male pupils' speech contribution and explore whether the varied reactions contribute to the development of different linguistic, gender and cultural identities of pupils in Serbian and Hungarian classes. The corpus was collected during the final year of a bilingual primary school in Subotica (Vojvodina) in 2015, and consists of the fine transcripts of two audio and video recordings of mother tongue lessons in Serbian and Hungarian classes. The results confirm the differences in feedback distribution and type in both classes regarding the pupils' gender. The teachers' feedback supports the higher status of male pupils in the group (class) and in relation to the teachers.
\end{abstract}

Keywords: classroom interaction, feedback, gender, Hungarian language, Serbian language

\section{INTRODUCTION}

Classroom talk is a form of complex group dialogue between a teacher and pupils with their predetermined roles, social positioning and individual speech styles. It is a staged communicative event, directed towards the fulfilling of teaching and learning goals and objectives, which occurs under controlled conditions within a limited time and space. Classroom discourse refers to the 
language used between teachers and pupils. Its traditional structure consists of Initiation-Response-Evaluation/Feedback (IRE/F) cycles and it allows a teacher to control who, when and how they speak, as well as the topic and very structure of classroom talk (McHoul, 1978; Swann, 1997; Cazden, 2001; Lefstein and Snell, 2011; Walsh, 2011). ${ }^{1}$

McHoul examines in what ways the rules of turn-taking management for natural conversation (Sacks et al., 1974) are to be modified to account for the organization of turn-taking in the classroom, and concludes that "only the teacher can direct speakership in any creative way” (McHoul, 1978, p. 188). Classroom talk is always pre-allocated: the teacher begins a 'talk-unit' (lesson) and corrects any deviation from the pattern Teacher-Pupil(s)-Teacher. Pupils' participation rights are limited to the choice between continuing or selecting the teacher as the next speaker. McHoul also listed technical differences between classroom talk and natural conversation: 1 . the potential for gaps and pauses is maximized, 2. the potential of overlaps is minimized, and 3. the permutability of turn-taking is minimized (McHoul, 1978, p. 188).

Lefstein and Snell (2011) indicate that the IRF/E model supports the uncritical acceptance of teachers' authority and teaching objectives, and therefore limits the development of pupils' thinking and their socialization. They propose the dialogic model of classroom discourse practice which focuses on the equal responsibility and equal opportunities of all participants to freely exchange ideas, to take an active role in meaning-making and to develop a collaborative and supportive learning community (Lefstein and Snell, 2011, p. 170).

Different contexts regulate classroom talk. The primary context is a lesson in a classroom, so that changes in classroom activities directly influence the way the language is used. Betsy Rymes (2008) distinguishes three dimensions of classroom discourse. The wider social context includes the social factors outside the immediate interaction that influence how words function in that interaction: the national education policy and curriculum, socioeconomic, ethnic and cultural backgrounds of pupils and teachers, and gender and other social norms. Interactional context refers to the sequential or other patterns of talk within an interaction that influence what can and cannot be said, and how

1 This three-part structure was first put forward by Sinclair and Coulthard in 1975 and is also known as a recitation script or tryadic structure (Walsh, 2011, p. 17). 
others interpret it within classroom discourse. Individual agency refers to the influence an individual can have on how language is used and interpreted in an interaction (Rymes, 2008, p. 31-32).

The teacher's language use is affected by the communicative event and social role in a given context, that is their personal (education, cultural and social status, ethnic group, age, sex/gender) and professional characteristics (attitudes and expectations, educational style), which may be more or less general or individual. They control and decide on the topics and who, when, how and how much a person speaks. The pupils' language use is also affected by the given communicative event and social role and their individual characteristics: age, sex/gender, ethnic group, family milieu, and previous knowledge (Ernst, 2002; Veith, 2005; Szépe, 2011).

The holistic theoretical approach provides the following conceptualization of classroom interaction. First, the linguistic production is seen as essentially dialogic, formed in the process of social interaction, so that the meaning emerges in the process of active understanding and response (Bakhtin, 1973). Second, gender itself is constituted trough verbal and nonverbal interaction (West and Zimmerman, 1987), and gender identities and power relations are highly contextualized and (re)produced through 'schooled language' (Swann, 2003). This is the language of teaching and learning, of a school and a classroom organization. It is part of the formal and informal ('hidden') curriculum which affects the socio-cognitive development of boys and girls as 'schooled subjects' and their experience of education (Swan, 2003). As a form of social interaction classroom talk directly and indirectly forms gender, cultural, ethnic and other components of pupils' identities. It is an important vehicle for learning "socially appropriate behaviour (including gender-appropriate behaviour)” (Swann, 1997, p. 18).

The feedback is information provided by a teacher regarding aspects of a pupil's performance or understanding. It occurs typically after instruction that seeks to provide knowledge and skills or to develop a particular attitude (Hattie and Timperley, 2007, p. 102). The feedback is an important feature of the three-part exchange, since it allows pupils to see whether their response has been accepted or not. Frequently, feedback entails some kind of evaluation, such as good, right, ok (Walsh, 2011, p. 17) and can be positive as well as 
negative. Any constructive encouragement in form of feedback can be motivational for pupils to improve their learning abilities and skills, to increase their knowledge and efforts, and to enhance self-esteem. It also regulates pupils' behaviour during class activities, i.e. reinforces desirable and discourages undesirable behaviour (Burnett, 2002, p. 6). Teachers should avoid being judgmental and especially forming feedback as negative critique related to pupils' personality and individual psychosocial features.

The teacher's feedback and evaluation is usually connected with their own expectations of the pupils' classroom performance. The so called 'Pygmalion effect' in the classroom suggests that teachers form initial expectations of pupils, who then behave in ways that confirm these (Brophy and Good, 1974; Kostović, 2008; Sadker and Zittleman, 2009): higher expectations thus lead to an increase in performance and low expectations lead to a decrease in performance. If teachers expect certain pupils to perform poorly because of some their characteristics (e.g. race, gender, intelligence scores, or economic status), then the pupils will indeed perform poorly because teachers will interact less and possibly more harshly with those students. This kind of approach fails to take into account the active, participatory role of the pupils in the interaction (Jones and Dindia, 2004, p. 456).

\section{PREVIOUS RESEARCH}

Various studies confirm the existence of gender bias in classroom interaction and the unequal and different treatment of boys and girls. They also show that teacher perceptions are consistent with stereotypes of gender differences in learning performance and abilities between boys and girls (Spender, 1990; Tiedemann, 2002; Frawley, 2005; Sadker and Zittleman, 2009).

Thus, Alyson Julé $(2002,2005)$ studied the amount of talk used by girls as opposed to boys in a grade 2 ESL classroom located in the Lower Mainland of British Columbia in teacher-led classroom lessons. Data were collected through videotaped observations and then transcribed. The findings revealed a particular lack of linguistic space in the girls' experience: they were limited in language in use and their silence appeared partly influenced by the teacher's response to their comments, which may impact language learning opportunities. Julé (2004) examined also how silence in language classrooms affects the 
construction of gender roles and how classroom habits create certain consistent behaviours. Her empirical studies confirmed that teachers ignore girls for long periods of time and that boys call out and dominate classroom talk, in addition to dominating the actual physical space.

Joachim Tiedemann (2002) studied the hypothesized biasing effect of teachers' gender role stereotypes on their impressions of their students' mathematical abilities and effort resources in mathematics. A total of 48 teachers participated in the study and responded to the questionnaires concerning their perceptions of about 300 of their third and fourth grade students. The findings confirmed the influence of stereotypes on teachers' perceptions of their students' mathematical abilities and effort, that boys have more developmental resources in mathematics.

Denn and others (2015) evaluated patterns of teacher-student interaction in German elementary schools during mathematics instruction. The authors studied differences in teachers' feedback behaviour regarding boys and girls. The results show that boys received more teacher reaction than girls, with the teachers also reacting more often to boys' misbehaviour and praising girls more often.

Hsiao-Ching She (2000) analysed the cross-relationships among a Taiwanese seventh-grade biology teacher's beliefs, practices and classroom interactions with either male or female students. She used classroom observation to determine gender-based differences during classroom interaction. The findings revealed the unequal distribution of direct questions, unbalanced feedback and encouragement, and a lack of restrictive control on calling out answers.

Tannen (1993) pointed out the differences in speech styles that boys and girls adopt when using language within their peer-groups, and considers them as different cultural groups. Speer (2005) concluded that variations in conversational patterns and speech styles are not solely determined by speakers' sex/ gender or by their belonging to a particular cultural group.

In this paper, we deal with a far more complex phenomenon that occurs during classroom interaction. We ask what this looks like in primary school classrooms in Vojvodina (Serbia) today, especially in bilingual ones, where two typologically different languages, Serbian and Hungarian, are taught and 
since greater gender equality has been declared as one of the aims of primary education in Serbia² (Bašaragin, 2016; Bašaragin and Savić, 2016).

The existing Serbian literature on classroom discourse focuses primarily on improving the academic achievement of pupils, and classroom interaction is studied only from the teaching-methodological perspective, aiming to improve professional competence of engaged teachers. The gender differences in classroom discourse have never been considered an issue in Serbian research papers. Therefore, we decided to deal with the complexity of classroom discourse by combining two approaches: discourse analysis (Ehlich, 1993; Savić, 1993) and gender studies (West and Zimmerman, 1987).

The aim of this paper is to determine the differences in the type of the teacher feedback and evaluation sequences after the female and/or male pupils' speech contribution, and to explore whether the diverse teacher's reactions contribute to the development of different linguistic, gender and cultural identities among pupils in Serbian and Hungarian classes during the final year of bilingual primary schools in Subotica (Vojvodina) in 2015.

In addition to Serbian, on the territory of Vojvodina (Serbia) there are nine other languages in official use that are spoken by the ethnic communities that live there: Bulgarian, Montenegrin, Czech, Croatian, Hungarian, Macedonian, Romanian, Ruthenian and Slovak. For some of these ethnic communities, depending on the number of children in a class, both primary and secondary education is organized in their mother tongues (this right is granted by the Serbian constitution). However, at the same time they are obligated to attend instruction in Serbian, the language of ethnic majority. For these people Serbian as an official language is termed a "non-mother tongue". There is no clear definition of this term in the literature, but it is usually considered a language adopted or learned in addition to the mother tongue: the second language.

Why should one compare Serbian and Hungarian classes in Vojvodina regarding gender issues? The classroom discourse and gender interaction within a

2 The Law on Basic Education System (National Assembly of the Republic of Serbia, 2019), Article 44, allows the implementation of the principle of equal opportunities and prohibition of discrimination in content and form of textbooks. 
classroom setting are underrepresented as research objectives in Serbian literature. Hungarian and Serbian are not only two typologically different languages, but Serbian is also the language of majority and Hungarian the language of "others". This opens up the possibility of different linguistic behaviour in the same context - classroom discourse.

The primary research questions are: 1 . What types of feedback sequences are present in Serbian and Hungarian classes? 2. Are there differences in feedback distribution regarding gender between Hungarian and Serbian classes? 3. Do the teachers evaluate the pupils' speech contributions differently regarding pupils' gender and the type of language used in the classroom?

\section{TRANSCRIPTION METHODOLOGY}

The transcription methodological framework is based on the discourse procedures in the transcription for verbal interaction (Savić, 1993) and partly on the HIAT2 transcription system for nonverbal communication and action (Ehlich, 1993). ${ }^{3}$

\subsection{Corpus}

The corpus consists of the fine transcript of two audio and video recordings of mother tongue lessons in Serbian (length 187'22") and Hungarian classes (length 164'50") during the final year of primary ${ }^{4}$ schools in Subotica, Vojvodina $^{5}$. The recordings ${ }^{6}$ were made in the spring of 2015, with two movable cameras, placed in the left and right corners of the classrooms, facing pupils diagonally next to the teacher's desk, and a tape recorder placed on the chair at the back of the classroom. The classroom setting is traditional, set up with five or six rows all facing the front. The teacher's desk is in front and so are the chalkboards. The aisles have enough space between them for the teacher to walk up to each pupil. This setup allows all the pupils to see the teacher and the board. In the Hungarian classroom there is also a computer in the right

\footnotetext{
3 Symbols used for transcription are given in the Appendix.

4 Primary school lasts eight years in Serbia, in the final year pupils are 14-15 years old.

5 Subotica is a town in the northern part of Serbia, in the province of Vojvodina.

6 We gained a written permit for video recording from the local educational advisor, directors of primary schools, as well as parents' approval.
} 
corner facing the teacher and an overhead projector above the teacher's desk facing the wall behind the teacher.

The Serbian class consists of 13 male and 7 female pupils and the Hungarian class of 7 male and 10 female pupils. Both teachers are women, the homeroom teachers for these classes, and they teach mother tongue lessons. During the recorded lessons pupils in both classes were working on literary texts: the main tasks were text comprehension and analysis (theme, genre, ideas, structure, and similar), but there were also some reading exercises. The lessons have the form of group discussions; they are frontal, teacher-centred and verbal.

The Serbian lesson was about the poem by a Serbian author, Jovan Jovanović Zmaj, "Svetli grobovi" ("Bright Graves"). It talks about the promise of descendants to continue what their ancestors began, a continuous sacrifice of many generations for a noble cause, and about a difficult but glorious past which helps new generations to find the right path into the future.

The Hungarian lesson was about a play by a Hungarian playwright, Spiró György, called "Esti müsor" (George Spiro: "Evening Program"). This modern drama is about the everyday life of the Hungarian middle class. There are four characters: two married couples, Bella and Béla, and Géza and Gizi, are having dinner together, watching TV. The focus is on their family life and their marriage problems.

\subsection{Unit of analysis}

The basic unit of analysis is one IRF/E-cycle presented in turn, consisting of multiple or single speech contributions of actors, which are further divided into single utterances as the smallest units of analysis (Excerpt 1).

\section{Excerpt 1}

\begin{tabular}{|c|c|c|c|}
\hline \multirow[t]{2}{*}{0328} & $\mathrm{~N}$ & VA & $\begin{array}{l}\text { I da li sada, deco, razumete } \int \\
{\left[\text { And do you, children, understand it now } \int\right]^{7}}\end{array}$ \\
\hline & & NA & o- - - - -stands by the desk, fa, loo at - - - \\
\hline \multirow[t]{2}{*}{0329} & & VA & Spo čemu su, deco, njihovi grobovi svetli? (..) \\
\hline & & & [ why, children, are their graves light? (..)] \\
\hline
\end{tabular}

7 All translations into English are done by the author. 


\begin{tabular}{|c|c|c|c|}
\hline \multirow{2}{*}{0330} & & \multirow[t]{2}{*}{ VA } & Pa na osnovu čega, $\int$ \\
\hline & & & [Well, why, $]$ \\
\hline & & NA & 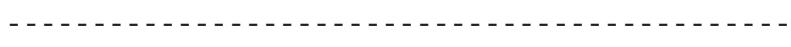 \\
\hline \multirow[t]{3}{*}{ o331 } & & VA & 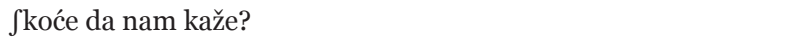 \\
\hline & & & [ $\int$ who is going to tell us?] \\
\hline & & NA &  \\
\hline \multirow[t]{3}{*}{0332} & Un & VA & Na osnovu njihovih dela. \\
\hline & & & [Because of their works.] \\
\hline & & NA & (many talking at once) \\
\hline \multirow[t]{3}{*}{0333} & $\mathrm{~N}$ & VA & Na osnovu njihovih dela koje su ostavili za vreme svog života, $\int$ \\
\hline & & & $\begin{array}{l}\text { [Because of their works which they left behind during their } \\
\left.\text { lives, } \int\right]\end{array}$ \\
\hline & & NA & - \\
\hline \multirow[t]{3}{*}{0334} & & VA & Jje l' tako? \\
\hline & & & [ isn’t it so?] \\
\hline & & NA & 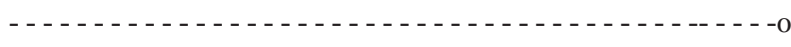 \\
\hline
\end{tabular}

\section{RESULT AND DISCUSSION}

\subsection{Quantitative results}

The quantitative results show differences in feedback distribution between the Serbian and Hungarian class and also differences regarding pupils' gender.

The total amount of teacher feedback sequences in the Serbian lesson is 98 , which makes up about $11 \%$ of the overall teacher's verbal activity during the lesson. While providing feedback, she addresses male pupils for $30 \%$ of her verbal activity, female pupils $26 \%$, male and female pupils $14 \%$, the whole class $30 \%$, and she evaluates her own speech contributions three times. A male pupil once gives feedback on a female pupil's answer.

In the Hungarian class the teacher's feedback sequences make up about $13 \%$ of her overall verbal activity ( 54 sequences). She directs her feedback to male pupils for $57 \%$ of her verbal activity, female pupils $34 \%$, male and female pupils $3 \%$, the class $5 \%$, and twice to herself. A male pupil once gives confirmatory feedback to a female pupil and once a female pupil gives the same to a male pupil.

The majority of the teacher's feedback sequences to male pupils in the Hungarian class is directly connected with the disproportion between the number of 
male and female pupils and their verbal activity: six out of seven male pupils and nine out of ten female pupils participate in the classroom discourse. A similar thing applies to the Serbian class, where male pupils exceed the number of female pupils: eight out of thirteen male pupils are verbally active as opposed to six out of seven female pupils.

The analysis reveals several basic types of teacher feedback and evaluation sequences in the form of the discourse strategies (Table 1). These can be labelled as:

(1) Positive: repetition of pupils' responses, addition of a response, confirmation, praising and thanking, and

(2) Negative: rejection of response, rebuke, ironic comment, criticism.

Table 1. Relative frequency of teacher feedback in Serbian and Hungarian class per 45-minute class period with regard to gender.

\begin{tabular}{|l|c|c|c|c|}
\hline Feedback type & $\mathbf{m}$ & $\mathbf{f}$ & $\mathbf{m}+\mathbf{f}$ & $\mathbf{c l a s s}$ \\
\hline Teacher positive feedback in the Serbian class & & & & \\
\hline Repetition of pupils' responses & 0.21 & 0.06 & 0.12 & 0.17 \\
\hline Confirmation & 0.08 & 0.15 & 0.02 & 0.1 \\
\hline Praising & 0.01 & - & 0.02 & 0.05 \\
\hline Teacher positive feedback in the Hungarian class & & & & \\
\hline Repetition of pupils' responses & 0.15 & 0.11 & - & 0.02 \\
\hline Addition of a response & 0.17 & 0.02 & - & - \\
\hline Confirmation & 0.19 & 0.15 & 0.02 & - \\
\hline Praising & 0.06 & 0.02 & 0.02 & 0.04 \\
\hline Thanking & 0.02 & 0.02 & - & - \\
\hline Teacher negative feedback in the Serbian class & & & & \\
\hline Rejection of response & 0.07 & - & - & - \\
\hline Rebuke & 0.07 & 0.14 & - & - \\
\hline Ironic comment & 0.07 & 0.21 & - & 0.21 \\
\hline Criticism & - & 0.21 & - & - \\
\hline
\end{tabular}

$\mathrm{m}=$ male pupils, $\mathrm{f}=$ female pupils, $\mathrm{m}+\mathrm{f}=$ male and female pupils

We detected the positive evaluation types of 'addition of a response' and 'thanking' only in the Hungarian class (Table 1). On the other hand, we identified a larger amount of negative feedback in the Serbian class, while there is only one feedback sequence in Hungarian class that contains this kind of feedback (the rejection of a female pupil's comments on lesson content). 
The relative frequency of teacher feedback in the Serbian and Hungarian classes per 45-minute class period in relation to gender is shown in Table 1. The collected data reveal that male pupils receive more teachers' positive feedback in both classes than female pupils. The negative feedback types of 'ironic comment' and 'criticism' seem to be reserved only for female pupils in the Serbian class. These results correspond with the data in the literature which show that female pupils experience different treatment in classrooms (Spender, 1990; Denn et al., 2015).

\subsection{Positive feedback}

\subsubsection{The confirmation and repetition of pupils' answers}

The confirmation and repetition of pupils' answers in order to evaluate them as correct are the most prevalent types of feedback in both classes. The Serbian teacher mostly uses the expressions dobro, $\mathrm{mh}$, naravno, tako je (good, $\mathrm{hm}$, of course, that is it) and the Hungarian teacher much the same, mh, igen, jó, igaz (hm, yes, good, that is it) in order to evaluate the pupils' answers as correct. The positive reaction is directed more at the male pupils in both classes (Table 1).

The following example (Excerpt 2) explains how this feedback is performed in classroom discourse.

In the Serbian lesson the teacher requests from the pupils to name some "glorious people" of Serbian history and culture. The pupils name mostly male authors and scientists: Milutin Milanković, Nikola Tesla, Vuk Karadžić, Mihajlo Pupin, etc. Excerpt 2 is a part of this larger exchange related to naming famous people. At this moment, the teacher wants to hear another representative of the glorious Serbian past (0302). The male pupil $\mathrm{U}_{5}$ gives the name of the same Serbian author whose poem is analysed in the lesson (0303). The teacher repeats the answer and confirms its correctness by adding "Dobro" (Good., 0304-0305). 


\section{Excerpt 2}

\begin{tabular}{|c|c|c|c|}
\hline \multirow[t]{2}{*}{0302} & \multirow[t]{2}{*}{$\mathrm{N}$} & \multirow[t]{2}{*}{ VA } & Onda? \\
\hline & & & [Then?] \\
\hline \multirow{4}{*}{0303} & \multirow{4}{*}{ U5 } & NA & o- - - - - leaning against the board, fac, loo at Un - - - -- - o \\
\hline & & VA & I Jova Zmaj. \\
\hline & & & [And Jova Zmaj.] \\
\hline & & NA & o- - - - - loo at $\mathrm{N}-\mathrm{u}^{-}$ \\
\hline \multirow[t]{3}{*}{0304} & \multirow[t]{6}{*}{$\mathrm{N}$} & VA & Čika Jova Zmaj. (..) \\
\hline & & & [Uncle Jova Zmaj] \\
\hline & & NA & o- - - - - leaning against the board, fac, loo at Un - - - - - - - \\
\hline \multirow[t]{3}{*}{0305} & & VA & Dobro.(..) Dobro, $\int$ \\
\hline & & & [Good. (..) Good, $\left.\int\right]$ \\
\hline & & NA & 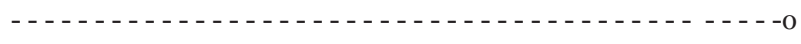 \\
\hline
\end{tabular}

The confirmation and repeating of the pupils' answers similarly occur in the Hungarian class.

\subsubsection{Praising}

Surprisingly, the teachers praise very seldom in both classes, although praise plays a very important role in the process of learning and socio-cognitive development of pupils (Burnett, 2002; Maclellan, 2005). The literature suggests that older pupils perceived praise after success or neutral feedback after failure as an indication that the teacher perceived their ability to be low. When given criticism after failure and neutral feedback after success, they perceived that the teacher had evaluated their ability to be high and their effort low (Hattie and Timperley, 2007, p. 97). The corpus reveals the following results. The Serbian teacher praises four times: twice the whole class with "Vi to lepo znate" (You know that very well, 0463) and "Lepo ste to zaključili" (You've concluded that very nicely, 0535), twice male pupils U3 and U5 with "Odlično" (Excellent, 0593) and once the male pupil U5 and female pupil Ua4 also with "Odlično" (Excellent, 1029). This praise is related to the pupils' good academic achievement, i.e. accurate conclusions about the topic they were discussing.

The next example in Excerpt 3 demonstrates how the Serbian teacher within only one complex IRF/E-exchange treats a male and female pupil differently, after right answering her question. 
In Excerpt 3 the Serbian teacher asks a question about the keywords from the poem (0794-0795). She addresses the whole class, using personal pronoun and a verb for the 2nd person plural (vi mislite) and without inserting any names. So, any pupil having an appropriate answer may begin and give an answer. The female pupil Ua4 answers correctly (0796). At that moment, the male pupil U5 turns back toward Ua4 because she sits in the back row and he in the middle row (0797). That tells us how much he is interested to see whether she is going to give correct answer or not, because the same female pupil succeeded several times before in giving correct answers and his own attempts failed. The teacher repeats the female pupil's answer and evaluates it as correct (0798). Then she requires further responses from the whole class (because she uses "children") (0799-0800) and the same male pupil U5 replies correctly (0801). The teacher's reaction is praise, with "excellent" (0802). Pupil $\mathrm{U}_{5}$ is very pleased with this positive evaluation, and he happily shakes his head and smiles (0803). The praise was omitted when the female pupil gave the correct answer, and thus the male pupil feels that his correct answer has higher value and his higher position in the class hierarchy is confirmed.

\section{Excerpt 3}

\begin{tabular}{|c|c|c|c|}
\hline \multirow[t]{3}{*}{0794} & \multirow[t]{3}{*}{$\mathrm{N}$} & VA & $\int<$ Šta vi mislite $\int$ \\
\hline & & & {$\left[\int<\right.$ What do you think $\left.\int\right]$} \\
\hline & & $\mathrm{NA}$ & o- -fac, loo at Un - - - - - - \\
\hline \multirow[t]{3}{*}{0795} & & VA & Skoje su ovo ključne reči?>> \\
\hline & & & [ what are those keywords?>] \\
\hline & & NA & 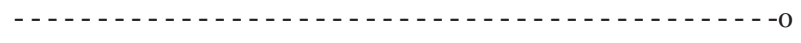 \\
\hline \multirow[t]{4}{*}{0796} & Ua4 & VA & Svetli grobovi. \\
\hline & & & [Light graves.] \\
\hline & & NA & o- - loo at $\mathrm{N}-\mathrm{o}$ \\
\hline & & & $===================$ \\
\hline \multirow[t]{3}{*}{0797} & $\mathrm{U}_{5}$ & VA & \\
\hline & & $\mathrm{NA}$ & $\%$ turns back toward Ua4 \\
\hline & & & o- - loo at Ua4 - - - - - o \\
\hline \multirow[t]{3}{*}{0798} & $\mathrm{~N}$ & VA & Tako je, svetli grobovi. $\int$ \\
\hline & & & [That's right, light graves.f] \\
\hline & & $\mathrm{NA}$ & o - - - -stands in front of the table, fac, loo at Un- - \\
\hline
\end{tabular}




\begin{tabular}{|c|c|c|c|}
\hline \multirow[t]{2}{*}{0799} & \multirow[t]{2}{*}{$\mathrm{N}$} & \multirow[t]{2}{*}{ VA } & SDalje. (..) \\
\hline & & & [ $\int$ Next. (..)] \\
\hline \multirow{3}{*}{0800} & & NA & o- - - fac, loo at Un- - - - - - - - - - \\
\hline & & VA & Šta bismo rekli, deco? \\
\hline & & & [What would we say, children?] \\
\hline \multirow{3}{*}{0801} & \multirow{3}{*}{$\mathrm{U}_{5}$} & NA & 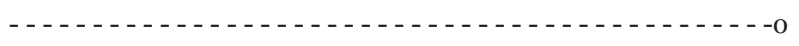 \\
\hline & & VA & Ideali. $\int$ \\
\hline & & & [Ideals. $\left.\int\right]$ \\
\hline \multirow{3}{*}{0802} & \multirow{3}{*}{$\mathrm{N}$} & NA & o- - loo at $\mathrm{N}-\ldots$ \\
\hline & & VA & $\int^{*}$ Odlično*, ideali. (...) \\
\hline & & & {$\left[\int^{*}\right.$ Excellent*, ideals. (...)] } \\
\hline \multirow{3}{*}{0803} & \multirow{3}{*}{$\mathrm{U}_{5}$} & NA & o- - fac, loo at U5 \\
\hline & & VA & \\
\hline & & NA & o- - -shaking head, smiling - - - - - \\
\hline
\end{tabular}

The Hungarian teacher praises five times: twice the whole class with "Így van, nagyszerü" (That's right, excellent, 048) and "Ügyesek vagytok” (You are clever, 050) for correct answering; once the male pupils $\mathrm{T} 1$ and $\mathrm{T} 33$ with "Nagyszerú! Jó." (Excellent! Good., 419) for taking the initiative in role assignment, and once the group of male and female student with "Nagyszerü" (Excellent, 510) after a reading exercise.

\subsubsection{Thanking}

One of the most interesting features of feedback sequences in the Hungarian class is the use of thanking, and we did not find this phenomenon in the Serbian lesson. On two occasions, both after reading exercises, the Hungarian teacher expresses thanks to the active female and male pupils for their efforts. She uses the expression "Jó, köszönjük" (Good, we thank you, 174) and the similar “Jó, elég, köszönjük szépen” (Good, that’s enough, we thank you very much, 613). These expressions are in the first-person plural. The teacher tries in this way to create an atmosphere of equal participation and mutual encouragement in classroom activities, and perhaps to underline belonging to same social (and cultural?) group.

The use of thanking as type of feedback sequence in classroom talk is in our opinion a linguistic and cultural phenomenon of Hungarian speakers. It 
allows the consideration of every speaker as equal regardless his/her actual conversational status. Unfortunately, there is still no research conducted on this to support this conclusion.

\subsection{Negative feedback}

\subsubsection{Criticism}

As we already mentioned, we detected the teacher's negative reaction only in the Serbian class. The most interesting type of negative feedback is criticism, because it applies the negative personal evaluation of pupils - it disrespects pupils' personalities and presents an assault on their integrity (Arsenović Pavlović et al., 2017; Burnett, 2002).

The collected data reveal only one occasion of critical feedback to one female pupil in the Serbian class. The following example in Excerpt 4 shows how the Serbian teacher criticizes the female pupil while at the same time not taking the opportunity to do the same to a male pupil.

The poem analysed in the Serbian lesson dates from $19^{\text {th }}$ century, and therefore contains lot of archaic words. In Excerpt 4 the Serbian teacher asks a question about any archaic words that the pupils do not understand, addressing the whole class (0951). The male pupil U5 gives an answer first, slightly after the teacher ended her turn (0952). But this answer has nothing to do with the question asked, so the teacher ignores it. Then, the female pupil Ua2 gives an answer (0953). The teacher repeats it, beginning with "Hm" (0954). In this way she clearly shows her attitude towards its content: she is not satisfied with it. The teacher's following comment is in fact a form of a negative critique, because she criticizes the female pupil's lack of knowledge (0955-0956). The teacher does not give any explanation of these words in the following lines, and the female pupil continues with giving further examples of archaic and incomprehensible words. 


\section{Excerpt 4}

\begin{tabular}{|c|c|c|c|}
\hline \multirow[t]{3}{*}{0951} & $\mathrm{~N}$ & VA & Koje su to reči? $\int$ \\
\hline & & & [What are these words? $]$ ] \\
\hline & & NA & o- - - - -stands 1 by the table, glasses in ha, fac, loo at Un - - - - -o \\
\hline \multirow[t]{3}{*}{0952} & $\mathrm{U}_{5}$ & VA & JTo je pogrešno. \\
\hline & & & [ $\int$ That is wrong.] \\
\hline & & NA & o- - - loo at N- - - - - - - - - - - - - - - - - - - - - - - \\
\hline \multirow[t]{3}{*}{0953} & $\mathrm{Ua} 2$ & VA & Golemo, ogromno, $* * * \int$ \\
\hline & & & {$\left[\int\right.$ Tremendous, huge, $\left.{ }^{* * *}\right]$} \\
\hline & & NA & 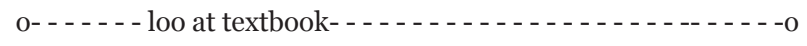 \\
\hline \multirow[t]{4}{*}{0954} & $\mathrm{~N}$ & VA & $\int$ Hm. Golemo i ogromno $\int$ \\
\hline & & & [ $\int \mathrm{Hm}$. Tremendous and huge $\left.\int\right]$ \\
\hline & & NA & $\%$ smiles \\
\hline & & & o- - - - -stands 1 by the table, glasses in ha, fac, loo at Ua2 - - - - - \\
\hline \multirow[t]{3}{*}{0955} & & VA & $\int<$ to nekada bi bilo *nepojmljivo* $\int$ \\
\hline & & & {$\left[\int<\right.$ it was *unthinkable* before $\left.\int\right]$} \\
\hline & & NA & 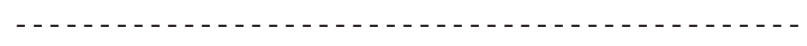 \\
\hline \multirow[t]{2}{*}{0956} & & VA & $\int$ da je to // da je to nepoznata reč. $>\int$ \\
\hline & & & [ $\int$ that this is // that this is an unknown word. $\left.>\int\right]$ \\
\hline
\end{tabular}

\subsection{Feedback omission}

The omission of the teacher feedback can have negative effects on pupil's self-esteem, and this strategy can be used for different treatment of male and female pupils (Frawley, 2005; Tannen, 1993). Spender (1990, p. 102-131) claims based on her own classroom discourse research that female pupils' spoken contributions to classroom discussions are largely ignored by teachers. They receive not only less attention from the teacher but must also wait longer to get it. In this way female pupils become invisible and less respected in the classroom.

The following examples in Excerpt 5 and Excerpt 6 illustrate the different treatment of male and female pupils when it comes to feedback practices in classroom discourse.

The part of the Hungarian lesson is dedicated to reading exercises and to improving reading comprehension. Three female pupils and two male pupils 
read the play aloud from the textbook. The excerpts below show two situations when one female pupil (TL3, Excerpt 5) and two male pupils ( $\mathrm{T}_{3}$ and $\mathrm{T} 1$, Excerpt 6) assign themselves the roles they want to read.

\section{Excerpt 5}

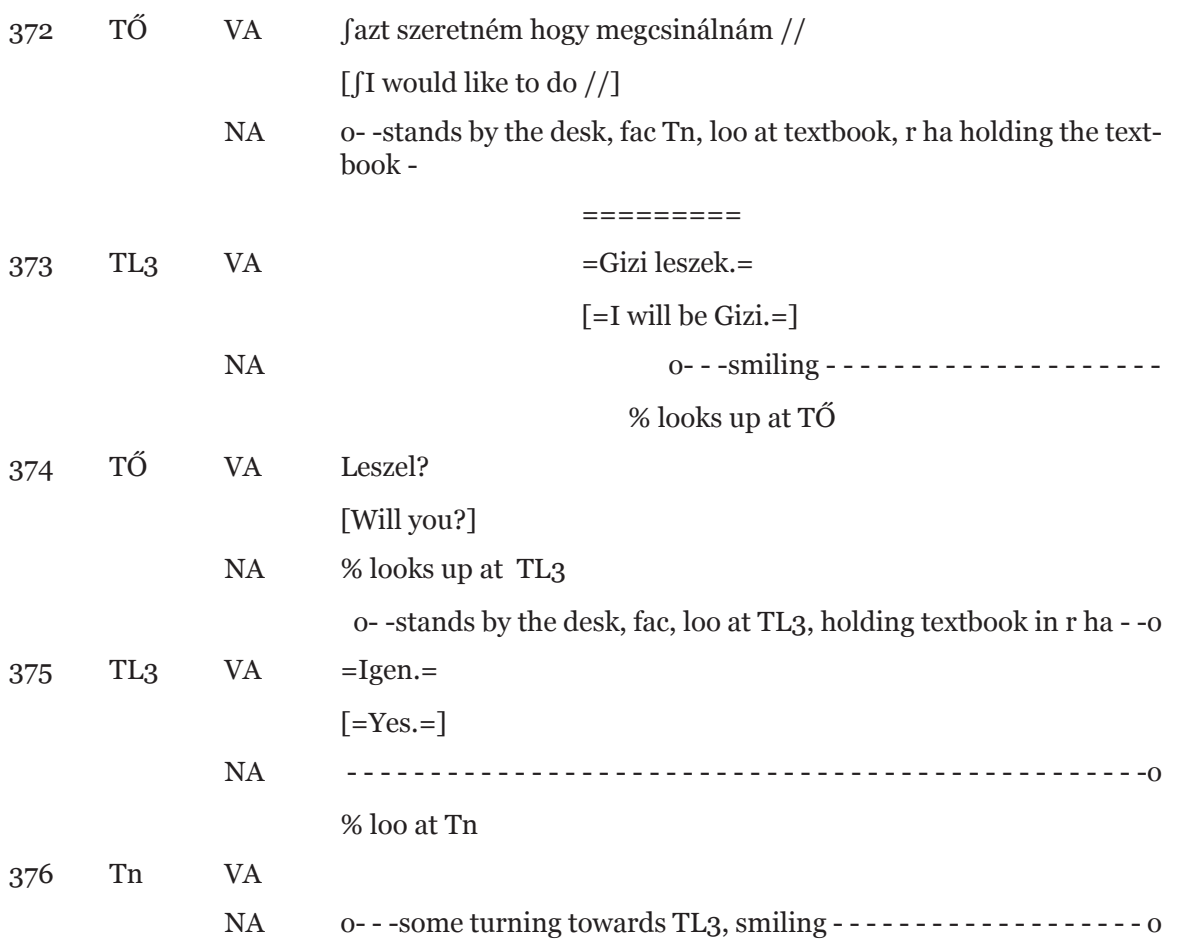

\section{Excerpt 6}

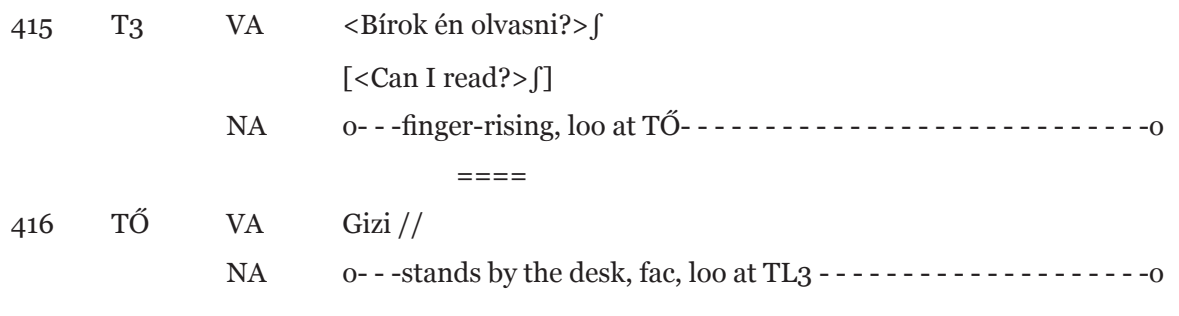




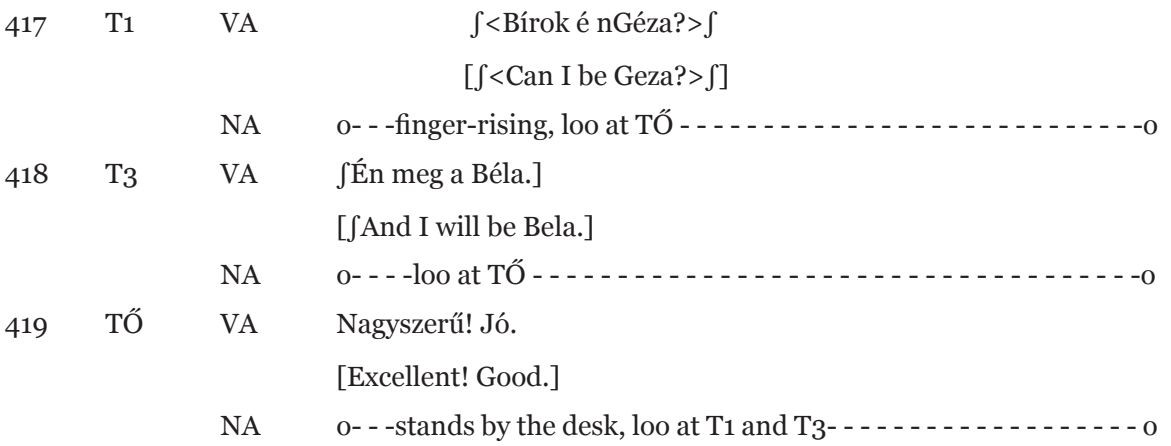

These two situations differ in the context and timing of occurrence. At the point when TL3 interrupts the teacher no one has mentioned any reading exercises or role assignment. The teacher explains at that moment some features of the dialogic forms in the text and then the female pupil interrupts her (372-373). That tells us two things. First, reading exercises are a common classroom activity, something that pupils expect to do when some new literary text or writer are introduced, and the teacher assumes with all certainty that she does not have to give any information about the activity. Secondly, the excerpts show that the female pupil (TL3) decides to act by interrupting the teacher's turn and expressing her willingness and desire 'to be' a character who she likes. She is the one who takes initiative first.

In Excerpt 6 the teacher, at that moment, carries out the actual role assignment. In the previous exchanges she had assigned the role of one female character and the narrator to two girls (TL8 and TL9). Now with an attempt at "Gizi//" (416) she wants to confirm the participation of TL3 (because she expressed this wish before, Excerpt 5). The male pupil T3 uses her intra-turn pause to state his wish to participate in the reading exercise in the form of a question (415), followed by the male pupil $\mathrm{T} 1$ who states also in the form of question that he wants to read the lines of one male character (417). Then $\mathrm{T} 3$ immediately extends his previous turn with the same wish as T1 (418).

In both examples the teacher's turns are interrupted, she stops her verbal activity and focuses on the questions posed by all the pupils. The difference lies in how she reacts. When the female pupil interrupts her, she responds in the form of the yes-no-question (374). She is not willing to get an answer (although the TL3 answers with "yes", 375), because feedback or evaluation is 
omitted. Therefore, TL3 doesn't actually know whether she is going to read or not. The teacher continues with further explanations. TL3 spoke when it was not allowed and got punished for it. On the other hand, the teacher's reaction to the male pupils' interruption is "Excellent! Good." (419). We can read this as: You did well, I am happy and proud of you and I support your initiative.

\section{CONCLUSION}

The analysis of teachers' feedback sequences in the Serbian and Hungarian classes showed differences in feedback type and distribution between the Serbian and the Hungarian class regarding pupils' gender. The 'confirmation' and 'repeating of pupils' answers' in order to evaluate them as correct are the most prevalent types of feedback. Moreover, male pupils receive more positive feedback from teachers in both classes than female pupils.

The positive feedback types of 'addition of a response' and 'thanking' appear only in the Hungarian class. The use of thanking as type of feedback sequence in classroom talk is in our opinion a linguistic and cultural phenomenon of Hungarian speakers. It allows the consideration of every speaker as equal regardless of his/her actual conversational status. Unfortunately, there is still no research conducted on this phenomenon to support this conclusion.

The negative feedback types 'ironic comment' and 'criticism' seem to be reserved only for female pupils in the Serbian class. The omission of feedback is also more commonly used after the correct answers of female pupils. The teachers not only fewer evaluations of female pupils' performance (regarding the number of male and female pupils in the classes) but also criticize female pupil's lack of knowledge, as in the Serbian lesson. They also ignore the poor performances or the wrong answers of male pupils and praise them more directly. Male pupils thus experience different treatment and receive more opportunities to participate in classroom discourse. That influences the positioning and image of male and female pupils in the classroom hierarchy, and the development of specific psychosocial features that support the higher status of male pupils in the group (class) and in relation to the teachers.

The limitations of this research are connected with the fact that a relatively small corpus (only two lessons in two classes) was analysed, so any kind of 
generalisation is excluded. It is necessary to conduct a wider research project, especially because the classroom discourse and gender interaction within a classroom setting are at this point more than underrepresented as research objectives in Serbian literature. The future research should include the broader linguistic, cultural, and social context (because of the wide range of languages spoken on the territory of Vojvodina) with a larger number of primary schools and videotaped lessons.

The classroom talk can be considered as a socialization model that affects the formation of stereotypical gender-based behavioural patterns of female and male pupils. The educational policy makers, national curriculum and textbook authors as well as teacher education program designers should thus make efforts to raise awareness about the importance of immediate classroom interaction, and aim to over the implicit gender-based discrimination that is part of teachers' explicit language use.

\section{REFERENCES}

Arsenović Pavlović, M., Antić, S., \& Jolić Marjanović, S. (2017). Pedagoška psihologija. Udžbenik sa priručnikom za vežbe [Educational psychology. Textbook and training manual]. Beograd: Univerzitet u Beogradu, Fakultet za specijalnu edukaciju i rehabilitaciju - Izdavački centar (ICF).

Bakhtin, M. M. (1973). Marxism and the philosophy of language. New York and London: Seminar Press.

Bašaragin, M. (2016). A társadalmi nem és a nyelv kölcsönhatása a tantermi beszélgetésekben - megszólítás [Interaction of gender and language in classroom talk - addressing]. Létünk, 56(4), 109-128.

Bašaragin, M. V., \& Savić, S. L. (2016). Rodno osetljiva analiza čitanki za osmi razred OŠ za srpski jezik, srpski kao nematernji i mađarski jezik [Gender sensitive analysis of the textbook for the eight grade of elementary school for Serbian, Serbian as second language and Hungarian language. In J. Milutinović (Ed.), Zbornik Odseka za pedagogïu, 25 (pp.75-97). doi: https://doi.org/10.1909o/zop.2016.25.75-97

Brophy, J. E., \& Good, T. L. (1974). Teacher-student relationships: Causes and consequences. New York: Holt, Rinehart, \& Winston. 
Burnett, P. C. (2002). Teacher praise and feedback and students' perceptions of the classroom environment. Educational Psychology, 22(1), 5-16.

Cazden, C. B. (2001). Classroom discourse: The language of teaching and learning. Portsmouth, NH: Heinemann.

Denn, A., Lotz, M., Theurer, C., \& Lipowski, F. (2015). „Prima, Lisa. Richtig“ und „Psst, Max. Hör auf zu stören!“ Eine quantitative Studie zu Unterschieden im Feedbackverhalten von Lehrkräften gegenüber Mädchen und Jungen im Mathematikunterricht des zweiten Schuljahres ['Well done, Lisa. Correct' and 'Shush, Max. Stop disrupting!' A quantitative study of differences in the teachers' feedback behavior regarding girls and boys in second grade elementary mathematics instruction]. Gender. Zeitschrift für Geschlecht, Kultur, Gesellschaft Journal for Gender, Culture and Society, 7(1), 29-47.

Ehlich, K. (1993). HIAT - A transcription system for discourse data. In J. A. Edwards and M. D. Lampert (Eds.), Talking data: Transcription and coding in discourse research (pp. 123-148). New York and London: Psychology Press.

Ernst, P. (2002). Pragmalinguistik, Grundlagen, Anwendungen, Probleme [Pragmalinguistics, principles, applications, problems]. Berlin and New York: Walter de Gruyter.

Frawley, T. (2005). Gender bias in the classroom: Current controversies and implications for teachers. Childhood Education, 81(4), 221-228.

Hattie, J., \& Timperley, H. (2007). The power of feedback. Review of Educational Research, 77(1), 81-112.

Hsiao-Ching, S. (2000). The interplay of a biology teacher's beliefs, teaching practices and gender-based student-teacher classroom interaction. Educational Research, 42(1), 100-111.

Kostović, S. (2008). Pigmalion u razredu [Pygmalion in the classroom]. Novi Sad: Filozofski fakultet, Odsek za pedagogiju.

Jones, S. M., \& Dindia, K. (2004). A meta-analytic perspective on sex equity in the classroom. Review of Educational Research, 74(4), 443-471.

Julé, A. (2002). Speaking Their Sex: A Study of Gender and linguistic Space in an ESL Classroom. TESL Canada Journal/Revue du Canada, 19(2), 37-51. doi: https://doi.org/10.18806/tesl.v19i2.928 
Julé, A. (2004). Gender, Participation and Silence in the Language Classroom: Sh-shushing the Girls. Basingstoke: Palgrave McMillan.

Julé, A. (2005). A fair share: Gender and linguistic space in a language classroom. Multilingua, 24(1-2), 25-37. doi: 10.1515/mult.24.1part2.25

Lefstein, A., \& Snell, J. (2011). Classroom discourse: The promise and complexity of dialogic practice. In S. Ellis and E. McCartney (Eds.), Applied Linguistics and Primary School Teaching (pp. 165-185). Cambridge: Cambridge University Press.

McHoul, A. (1978). The organization of turns at formal talk in the classroom. Language in Society, 7(2), 183-213.

Maclellan, E. (2005). Academic achievement: The role of praise in motivating students. Active learning in higher education, 6(3), 194-206.

National Assembly of the Republic of Serbia. (2019). Zakon o osnovama sistema obrazovanja i vaspitanja [The Basic Education System Act]. Službeni glasnik RS no. 88/2017, 27/2018, and 10/2019.

Rymes, B. (2008). Classroom discourse analysis: A tool for critical reflection. Cresskill, NJ: Hampton Press.

Sacks, H., Schegloff, E. A., \& Jefferson, G. (1974). A simplest systematics for the organization of turn-taking for conversation. Language, 5O(4), 696-735.

Sadker, D., \& Zittleman, K. R. (2009). Still failing at fairness: How gender bias cheats girls and boys in school and what we can do about it. New York, London, Toronto, Sydney: Simon and Schuster.

Savić, S. (1993). Diskurs analiza [Discourse analysis]. Novi Sad: Filozofski fakultet.

Smith-Lovin, L., \& Brody, C. (1989). Interruptions in group discussions: The effect of gender and group composition. American Sociological Review, 54(3), 424-435.

Spender, D. (1990). Mit Agressivität zum Erfolg: Über den doppeltlen Standar, der in den Klassenzimmern operiert [With aggressiveness to success: About the double standard in the classrooms]. In S. Trömel-Plötz (Ed.), Gewalt durch die Sprache. Die Vergewaltigung von Frauen in Gesprächen [Violence through language: The rape of women in conversations] (pp. 71-98). Frankfurt am Main: Fischer Taschenbücher Verlag. 
Swann, J. (1997): Talk control: An illustration from the classroom of problems in analysing male dominance of conversation. In C. Logan (Ed.), Gender perspectives on writing and language (pp.16-21). Ontario: Broadview Press.

Swann, J. (2003). Schooled language: Language and gender in educational settings. In J. Holmes \& M. Miriam (Eds.), The Handbook of Language and Gender (pp. 624-644). Maiden, Oxford and Berlin: Blackwell Publishing.

Szépe, Gy. (2011). Mother tongue competence and socio-professional integration into the community. In V. Vasić (Ed.), Jezik u upotrebi: Primenjena lingvistika u čast Ranku Bugarskom [Language in use: Applied linguistic in honour of Ranko Bugarski] (pp. 219-220). Novi Sad: Filozofski fakultet; Beograd: Filološki fakultet.

Tiedemann, J. (2002). “Teachers' Gender Stereotypes as Determinants of Teacher Perceptions in Elementary School Mathematics”. Educational Studies in Mathematics, 5o(1), 49-62.

Trömel-Plötz, S. (1991). Frauensprache: Sprache der Veränderung [Women's language: The language of change]. Frankfurt am Main: Fischer Taschenbuch Verlag.

Veith, W. H. (2005). Soziolinguistik. Ein Arbeitsbuch mit 104 Abbildungen, Kontrollfragen und Antworten [Sociolinguistics: A workbook with 104 illustrations, control questions and answers]. Tübingen: Gunther Narr Verlag.

Walsh, S. (2011). Exploring classroom discourse: Language in action. London and New York: Routledge.

West, C., \& Zimmerman, D. H. (1987). Doing Gender. Gender and Society, 1(2), 125-151. 


\section{Appendix: Symbols used in transcription}

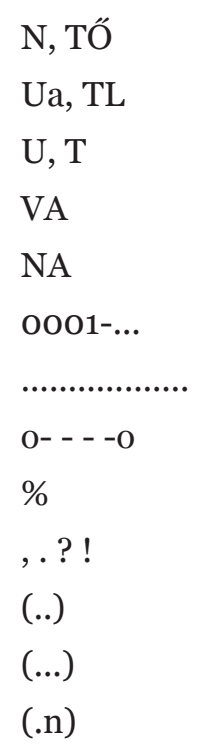

*text between these signs*

-text between these signs-

$=$ text between these signs $=$ $<$ text between these signs $>$ $>$ text between these signs $<$ //

$======$

$\int$

[]

loo

fac

ha

$\mathrm{r}$

1 teacher

female pupil

male pupil

verbal activity

nonverbal activity

number of sequences

beginning and ending of IRE/F cycles

duration of NA

momentariness of NA

punctuation

short pause

longer pause

very long pause

particularly emphasized

loudly pronounced

quietly pronounced

quickly pronounced

slowly pronounced

unfinished sequence, (self)repair

overlap

latching

translation

looking at

facing

hand(s)

right

left 


\title{
VIDIK SPOLA PRI RAZREDNI INTERAKCIJI MED UČITELJI IN UČENCI: POVRATNE INFORMACIJE IN OCENJEVANJE
}

\begin{abstract}
Različne raziskave potrjujejo, da pri izmenjavah v učilnici prihaja do neenake obravnave fantov in deklet. Namen članka je določiti razlike v učiteljskem odzivu po govornem udejstvovanju šolarjev in šolark, hkrati pa ugotoviti, ali različni tipi odzivov učitelja pomagajo krepiti različne jezikovne, spolne in kulturne identitete učencev v srbskih in madžarskih razredih. Korpus je bil leta 2015 sestavljen iz prispevkov zadnjega razreda dvojezične osnovne šole v Subotici (Vojvodina), sestoji pa iz transkripcij dveh zvočnih in video posnetkov pouka maternega jezika v srbskih in madžarskih razredih. Rezultati potrjujejo razlike pri tipu in distribuciji povratnih informacij učitelja $\mathrm{v}$ obeh razredih glede na spol. Povratne informacije učiteljev podpirajo višji status fantov v skupini (razredu) v v razmerju do učitelja.
\end{abstract}

Ključne besede: interakcija v razredu, povratne informacije, družbeni spol, madžarščina, srbščina

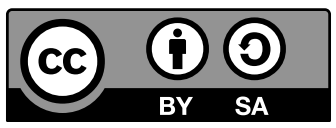

To delo je ponujeno pod licenco Creative Commons: Priznanje avtorstva-Deljenje pod enakimi pogoji 4.o Mednarodna. / This work is licensed under the Creative Commons Attribution-ShareAlike 4.o International.

https://creativecommons.org/licenses/by-sa/4.o/ 